\title{
PRODUCTION OF HYDROGEN BY PURPLE NON-SULFUR BACTERIA RHODOPSEUDOMONAS YAVOROVII IMV B-7620
}

\author{
O.V. Tarabas', S.O. Hnatush', O.B. Tashyrev ${ }^{2}$, V.M. Hovorukha ${ }^{2}$, \\ O.A. Havryliuk', O.M. Moroz, A.A. Halushka ${ }^{1}$
}

${ }^{\prime}$ Ivan Franko National University of Lviv, 4 Hrushevsky Str., Lviv, 79005, Ukraine

${ }^{2}$ Zabolotny Institute of Microbiology and Virology, NAS of Ukraine, 154 Acad. Zabolotny Str., Kyiv, 03143, Ukraine

e-mail: otarabas@gmail.com

\begin{abstract}
Hydrogen production by microorganisms is studied by using different sources of carbon for their cultivation. Purple non-sulfur bacteria are capable of producing molecular hydrogen phototrophically with the simultaneous accumulation of biomass on organic substrates that may be waste from various industries. That fact makes the study of this group of microorganisms very much promising. The aim. The determination of the ability of purple non-sulfur bacteria Rhodopseudomonas yavorovii IMV B-7620 to produce hydrogen consuming different organic substrates and their effects on the main metabolic indicators of culture growth. Methods. Bacteria were grown in $100 \mathrm{~mL}$ glass jars in liquid modified ATCC No. 1449 medium for 14 days at temperature $+27 \ldots+30{ }^{\circ} \mathrm{C}$ and at constant light (200 lux). Biomass accumulation and hydrogen production in the cultivation medium were determined using sodium acetate (12 and $36 \mathrm{mM})$, malate (12 and $36 \mathrm{mM})$, succinate $(36 \mathrm{mM})$, glucose $(36 \mathrm{mM})$, starch $(36 \mathrm{mM})$, sodium citrate $(36,60,90 \mathrm{mM})$. Biomass was determined turbidimetrically, the composition of the gas phase was determined using a gas chromatograph LHM-8-MD, redox potential and $p H$ were estimated potentiometrically. The volume of gas synthesized was measured on a syringe scale. Determination of the content of organic acids in the culture liquid was analyzed by high performance liquid chromatography. Results. The utilization of organic compounds (malate, glucose, starch, sodium citrate) by R. yavorovii IMV B-7620 is accompanied by hydrogen synthesis. Under the growth with sodium acetate, bacteria produce small amounts of succinate. The malate metabolism results in the production of small amounts of fumarate on the $7^{\text {th }}$ day of cultivation and isocitrate on the $10^{\text {th }}$ day of cultivation. On the $14^{\text {th }}$ day of cultivation, the cultural liquid contains a small amount of succinate. On the $14^{\text {th }}$ day of cultivation, $R$. yavorovii IMV B-7620 produces $7.64 \pm 0.04 \%$ of hydrogen in the medium with malate $(36 \mathrm{mM})$. However, the maximum concentration of hydrogen in the gas phase $(21.26 \pm 0.08 \%)$ was gained on the $14^{\text {th }}$ day of cultivation in the medium with sodium citrate. The maximum concentration of $\mathrm{H}_{2}$ in the gas phase during the growth in the medium with sodium citrate $(60 \mathrm{mM})$ and $\mathrm{NH}_{4}^{+}$was $27.83 \pm 5.46 \%$ on the $7^{\text {th }}$ day of cultivation and $35.69 \pm 0.40 \%$ with increasing concentration of sodium citrate up to $90 \mathrm{mM}$ on the $10^{\text {th }}$ day of cultivation. The total volume of hydrogen was $25.54 \pm 0.49 \mathrm{~mL}$ of $\mathrm{H}_{2}$ during the growth of R. yavorovii IMV B-7620 in the medium with $90 \mathrm{mM}$ sodium citrate and $\mathrm{NH}_{4}^{+}$. That is 1.5 times more than the amount of $\mathrm{H}_{2}$ produced during the growth of bacteria in the medium with $60 \mathrm{mM}$ sodium citrate with the addition of $\mathrm{NH}_{4}^{+}$. Conclusion. Purple non-sulfur bacteria $\mathrm{R}$. yavorovii IMV B-7620 synthesize hydrogen during photofermentation of organic compounds. Bacteria were isolated from the water of Yavoriv Lake (Lviv region, Ukraine) formed as a result of flooding of the sulfur quarry. Bacteria consume sodium citrate, malate, glucose, starch and emit hydrogen. The total volume of hydrogen during the growth of R. yavorovii IMV B-7620 in the medium with $90 \mathrm{mM}$ sodium citrate and $\mathrm{NH}_{4}^{+}$is $25.54 \pm 0.49 \mathrm{~mL} \mathrm{H}_{2}$.
\end{abstract}

Keywords: hydrogen, purple non-sulfur bacteria, photofermentation.

Fossil fuels are widely used to meet the needs of the mankind, but its world reserves are constantly declining. The main cause of climate change is the application of fossil fuels and inefficient consumption of energy produced. According to the forecasts of the leading international research centers for climate research, the temperature will rise by $2-5{ }^{\circ} \mathrm{C}$ over the next century. That will 
cause climate change and various ecosystems will be threatened with extinction [1]. The concerns about climate change and declining oil reserves are promoting the search of alternative fuel sources. Hydrogen may be one of them. Therefore, the research on its production, storage and usage is being conducted. Hydrogen gives a much higher energy yield than natural gas, oil or coal. The product of hydrogen combustion is only water, which is completely safe for the environment. These facts make it a promising type of energy [2-4].

Various technologies of hydrogen production have been developed: water electrolysis, thermochemical production and biological production. Biological hydrogen production is the least harmful for the planet. It takes place due to the photolysis of water with algae and cyanobacteria or enzymatic production from organic compounds involving microorganisms, in particular, photosynthetics or using mixed cultures of photo- and chemosynthetics $[5,2,4]$. Isolation and study of typical strains of $\mathrm{H}_{2}$-forming phototrophic bacteria is necessary for targeted regulation of $\mathrm{H}_{2}$ formation in technological processes by a combination of non-photosynthetic and photosynthetic bacteria in a hybrid system that can increase hydrogen yield [6, 2].

Photosynthetic green plants and cyanobacteria are autotrophs that perform photolysis of water at light $[6,7]$. Heterotrophs use organic substrates to produce hydrogen under anaerobic conditions at light or in the dark conditions. So, these processes are called photofermentation or chemofermentation. Bacteria are capable of consuming of various organic compounds (carbohydrates, proteins, fats, complex organic substrates) in the process of chemofermentation and producing of hydrogen [8]. Purple non-sulfur bacteria perform photofermentation of various organic acids (acetic, malonic) or glucose, as well as other organic substances, utilizing them as carbon sources and electron donors [5, 9]. Hydrogen generation by photosynthetic microorganisms occurs through the application of sunlight or artificial lighting, which provides the economical usage of energy [5]. Lightdependent hydrogen production by photosynthetic bacteria was first studied in Rhodospirillum rubrum. Microorganisms were cultivated anaerobically at light in medium containing dicarboxylic acids of the citric acid cycle and either glutamate or aspartate as a source of nitrogen $[10,11]$. The energy conversion efficiency and the optimal carbon source are the key factors for hydrogen production in biological systems [6].
Hydrogen production by microorganisms has been studied using various substrates as the sources of energy [12-17]. Purple non-sulfur bacteria are capable of producing hydrogen phototrophically simultaneously using organic substrates such as wastes of various industries, which makes the study of this group of microorganisms promising $[18,19]$.

The aim of our study was to determine the ability of purple non-sulfur bacteria Rhodopseudomonas yavorovii IMV B-7620 to produce hydrogen consuming different organic substrates and their effect on the main metabolic indicators of culture growth.

Materials and methods. Bacteria $R$. yavorovii IMV B-7620, isolated from Yavoriv Lake were used for the research. The strain was obtained in pure culture and identified at the Department of Microbiology of Ivan Franko National University of Lviv [20]. Bacterial culture is stored in the Depository of the D. K. Zabolotny Institute of Microbiology and Virology of the NAS of Ukraine.

Bacteria were grown in the glass jar with a volume of $100 \mathrm{~mL}$ in a liquid modified medium ATCC No. 1449 of the following composition $(\mathrm{g} / \mathrm{L})$ : ammonium chloride -0.4 ; potassium dihydrogen phosphate -0.6 ; calcium chloride dihydrate -0.05 ; magnesium sulfate heptahydrate -0.32 . The $\mathrm{pH}$ of the cultivation medium was 7.0. Microorganisms were cultivated for 14 days at the temperature of $+27 \ldots+30{ }^{\circ} \mathrm{C}$ and under constant light (200 lux).

The consumption of organic carbon sources was studied for 14 days, determining the accumulation of biomass and hydrogen production in the cultivation medium with the addition of sodium acetate (12 and $36 \mathrm{mM})$, malate (12 and $36 \mathrm{mM})$, succinate $(36 \mathrm{mM})$, glucose $(36 \mathrm{mM})$, starch (36 mM), sodium citrate $(36,60,90 \mathrm{mM})$. The biomass of bacteria was determined turbidimetrically using a photoelectrocolorimeter KFK-3 ( $\lambda=660 \mathrm{~nm}$, cuvette with $3 \mathrm{~mm}$ optical path). Calculation formula is $C=\left(E_{660} \cdot n\right) / 0.17 \pm 0.01$, where $\mathrm{C}$ is biomass, $\mathrm{g} / \mathrm{L} ; E_{660}-$ extinction at $\lambda=$ $=660 \mathrm{~nm} ; n$-dilution; $0.17-$ conversion factor calculated by weight method.

To sample the gas and cultural liquid, 2.5, 11 and $50 \mathrm{~mL}$ plastic sterile syringes (Bayer) were used. Samples were collected by piercing the rubber stopper of the vial with a needle. The volume and composition of the synthesized gas were determined on the $3^{\text {rd }}, 7^{\text {th }}, 10^{\text {th }}$, and $14^{\text {th }}$ days of cultivation. The volume of gas synthesized was 
measured on a syringe scale (displacement of the syringe piston by the residual gas pressure). The composition of the gas phase was determined using the gas chromatographer LHM-8-MD [21]. Two steel columns were used - the first (I) one was used to determine $\mathrm{H}_{2}, \mathrm{O}_{2}, \mathrm{~N}_{2}$ and $\mathrm{CH}_{4}$, the second (II) one was used to determine $\mathrm{CO}_{2}$. Column parameters were $\mathrm{I}-l=3 \mathrm{~m}, d=3 \mathrm{~mm}$, sorbent $13 \mathrm{X}(\mathrm{NaX})$; II $-l=2 \mathrm{~m}, d=3 \mathrm{~mm}$, Porapak-Q sorbent; temperature of columns, evaporator and detector was $+50{ }^{\circ} \mathrm{C}$, detector current was $50 \mathrm{~mA}$. Carrier gas was argon, gas flow rate was $30 \mathrm{~mL} / \mathrm{min}$. The dynamics of fermentation of substrates was studied by the following parameters: volume and composition of the formed gas, $\mathrm{Eh}, \mathrm{pH}$, biomass accumulation. The redox potential (Eh) and $\mathrm{pH}$ were determined by the potentiometric method. Potentiometric measurement of Eh was performed using a pair of electrodes (platinum measuring electrode EPV-1 and silver chloride reference electrode EVL-1M3). The $\mathrm{pH}$ measurements were performed using a combined electrode ESC10603/4.

Studies of the utilization of malate and sodium acetate by $R$. yavorovii IMV B-7620 were carried out by high performance liquid chromatography (HPLC) using the Varian ProStar chromatographic system. The chromatographic system consisted of two Varian ProStar 210 pumps (Agilent Technologies, Singapore), Polaris 5 C18-A column (Agilent Technologies, Netherlands), 250×4.6 mm in Varian ProStar 500 column module (Agilent Technologies, Australia), Varian ProStar 335 UV-visible photodiode array detector (Agilent Technologies, Australia). Two solvents were used as the mobile phase: solution A was acetonitrile, solution B was $0.2 \%$ solution of trifluoroacetic acid (for analysis, AppliChem, Germany) in water obtained using the water purification system Adrona Crystal E Bio with ultrafilter Milipore (Adrona, Latvia). Chromatographic separation was performed in $0.2 \%$ trifluoroacetic acid solution for $8 \mathrm{~min}$. The solvent flow was $1.5 \mathrm{~mL} / \mathrm{min}$ [22]. Chromatograms were recorded at $\lambda=210 \mathrm{~nm}$. The column temperature was $+35^{\circ} \mathrm{C}$. The cultural liquid was analyzed for organic acid content before the start of cultivation and on the $3^{\text {rd }}, 7^{\text {th }}, 10^{\text {th }}$ and $14^{\text {th }}$ days of cultivation in modified medium ATCC No. 1449 with the addition of sodium acetate and malate at a concentration of $12 \mathrm{mM}$. Statistical processing of research results and plotting was performed using the program "Microsoft Excel $365^{\prime \prime}$.
Results. Purple non-sulfur bacteria perform photofermentation of various organic substrates $[5,23,24]$. That is why $R$. yavorovii IMV B-7620 bacteria were tested for the ability to produce hydrogen in a media with sodium acetate and malate at a concentration of $12 \mathrm{mM}$. Chromatographic analysis of the cultural liquid after the growth of $R$. yavorovii IMV B-7620 bacteria in the medium with sodium acetate showed that the cells consumed it completely on the $14^{\text {th }}$ day of cultivation. Under these conditions, microorganisms produced small amounts of succinate, followed by its further utilization. During the addition of malate into the cultivation medium, its depletion was also observed on the $14^{\text {th }}$ day of cultivation. The intermediates of malate metabolism were small amounts of fumarate on the $7^{\text {th }}$ day of cultivation and isocitrate on the $10^{\text {th }}$ day of cultivation. A small amount of succinate was found in the cultural liquid on the $14^{\text {th }}$ day of cultivation (Table 1).

As it was shown earlier, bacteria under study did not produce molecular hydrogen growing in the medium with sodium acetate at a concentration of $12 \mathrm{mM}$. Growing in the medium with $12 \mathrm{mM}$ of malate, bacteria $R$. yavorovii IMV B-7620 accumulated 1.5 times more biomass comparing to the medium with sodium acetate. On the $7^{\text {th }}$ and $14^{\text {th }}$ days of cultivation in medium with malate (12 mM), hydrogen concentration was $0.15 \pm 0.01$ and $1.5 \pm 0.03 \%$, respectively [25].

Increase in the concentration of malate to $36 \mathrm{mM}$ led to an increase in hydrogen production by $R$. yavorovii IMV B-7620 (7.64 $\pm 0.04 \%)$ on the $14^{\text {th }}$ day of cultivation. When the concentration of sodium acetate increased to $36 \mathrm{mM}$, the formation of hydrogen by the studied microorganisms was not found. During the growth of $R$. yavorovii IMV $\mathrm{B}-7620$ in the medium with $36 \mathrm{mM}$ of malate, bacteria accumulated 1.6 times more biomass comparing to the medium with sodium acetate (Table 2). Bacteria accumulated more biomass when grown in the medium with sodium citrate than in the medium with starch on the $14^{\text {th }}$ day of cultivation. However, during the photofermentation of starch, the concentration of hydrogen in the gas phase was $13.87 \pm 0.06 \%$ on the $14^{\text {th }}$ day of cultivation. A slight accumulation of biomass of $R$. yavorovii IMV B-7620 was observed in the process of growth in media with succinate or glucose (Table 2).

The $\mathrm{pH}$ is one of the important environmental factors that affect cellular metabolism, enzymatic activity and cell growth of microorganisms [16]. 


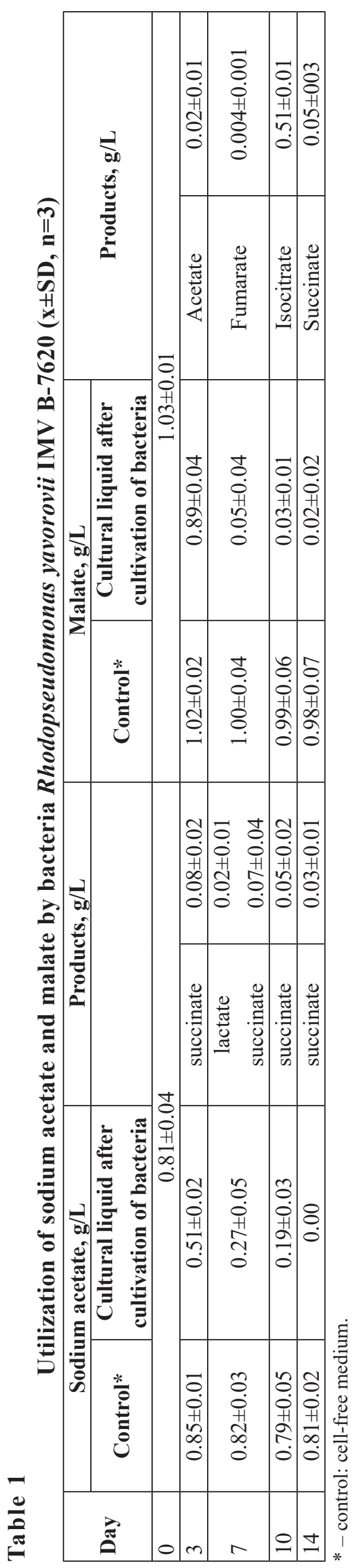

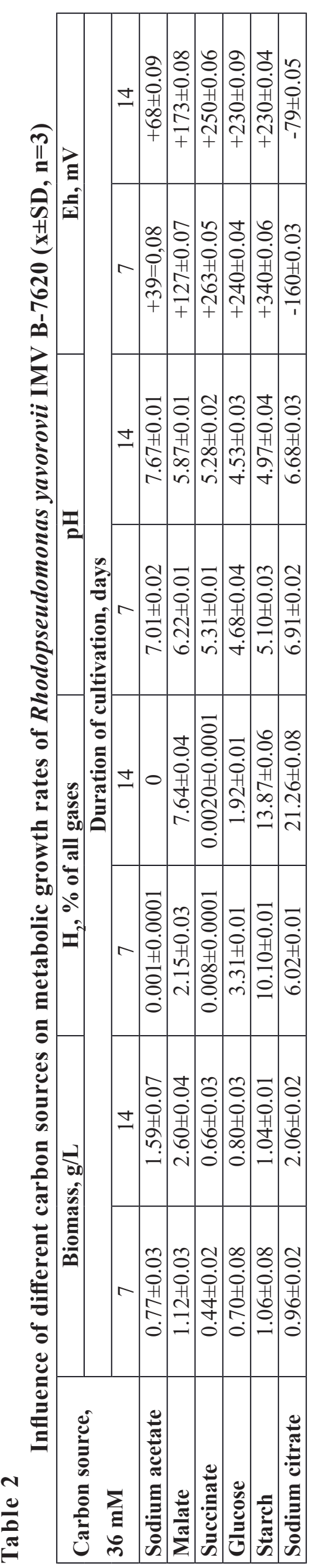

ISSN 1028-0987. Мікробіол. журн., 2021, Т. 83, № 5 
Using media with different organic acids for the cultivation of $R$. yavorovii IMV B-7620, the decrease of $\mathrm{pH}$ to 4.53 was observed. However, during the growth of bacteria in the medium with sodium citrate, the $\mathrm{pH}$ fluctuated only in the range of 6.91-6.68 (Table 2). The process of consumption of organic compounds under these conditions was accompanied by the synthesis of hydrogen. The maximum concentration of hydrogen in the gas phase $(21.26 \pm 0.08 \%)$ was determined on the $14^{\text {th }}$ day of cultivation in the medium with the addition of sodium citrate (Table 2). Therefore, sodium citrate was selected for further studies of hydrogen production by bacteria.

The yield of hydrogen in the process of photofermentation with the participation of purple bacteria depends on many factors. Hydrogen yield is affected by light intensity, excessive or insufficient concentration of the substrate, the presence of ammonium ions or contamination of the environment [5].

The effect of different concentrations (60, $90 \mathrm{mM}$ ) of sodium citrate in the medium with $\mathrm{NH}_{4}^{+}$ on the accumulation of biomass by microorganisms and hydrogen production was studied. Bacteria accumulated biomass of $3.98 \pm 0.05$ and $3.66 \pm$ $\pm 0.03 \mathrm{~g} / \mathrm{L}$, respectively, on the $14^{\text {th }}$ day of cultivation at concentrations of 60 and $90 \mathrm{mM}$ of sodium citrate with the addition of $0.4 \mathrm{~g} / \mathrm{L}$ of ammonium chloride (Fig. 1). Without the addition of $\mathrm{NH}_{4}^{+}$into the cultivation medium, the biomass of $R$. yavorovii IMV B-7620 on the $14^{\text {th }}$ day of cultivation remained at the level of the $3^{\text {rd }}$ day culture. Under these conditions, the redox potential on the $3^{\text {rd }}, 7^{\text {th }}, 10^{\text {th }}$ and $14^{\text {th }}$ days decreased to $-98 ;-105 ;-198 ;-153$ and $-79 ;-98 ;-179 ;-146 \mathrm{mV}$, respectively. A low value of Eh is a necessary condition for the growth of anaerobic $\mathrm{H}_{2}$-forming bacteria, the optimal range for which is $-150 \ldots-340 \mathrm{mV}$. The $\mathrm{pH}$ value for the growth in media with 60 or $90 \mathrm{mM}$ of sodium citrate with $\mathrm{NH}_{4}^{+}$ranged from 6.9 to 7.02 .

There was a significant decrease in the concentration of $\mathrm{O}_{2}$ in the gas phase on the $3^{\text {rd }}$ day of cultivation from $21 \%$ to $4.11 \pm 0.07$ and $3.94 \pm 0.14 \%$, respectively, grown in media with sodium citrate at concentrations of 60 and $90 \mathrm{mM}$ with the addition of $\mathrm{NH}_{4}^{+}$. On the $7^{\text {th }}$ day, there was no $\mathrm{O}_{2}$ in these two media (Fig. 2, 3). The maximum concentration of $\mathrm{H}_{2}$ during the growth in the medium with sodium citrate $(60 \mathrm{mM})$ and $\mathrm{NH}_{4}^{+}$was $27.83 \pm 5.46$ on the $7^{\text {th }}$ day of cultivation (Fig. 2). After the increasing of the concentration of sodium citrate up to $90 \mathrm{mM}$ it reached $35.69 \pm 0.40 \%$ on the $10^{\text {th }}$ day of cultivation (Fig. 3).

No residual gas was formed by bacteria on the $3^{\text {rd }}$ day of the growth in the medium with 60 and $90 \mathrm{mM}$ of sodium citrate and $\mathrm{NH}_{4}^{+}$. Gas formation was observed on the $7^{\text {th }}$ day of cultivation. Its volume was $8.14 \pm 0.14 \mathrm{~mL}$ in the medium with $90 \mathrm{mM}$ of sodium citrate and $\mathrm{NH}_{4}^{+}$and $7.96 \pm 0.69 \mathrm{~mL}$ in the medium with $60 \mathrm{mM}$ of sodium citrate and $\mathrm{NH}_{4}^{+}$. The maximum volume of gas formed was $7.37 \pm 0.12$ and $10.61 \pm 0.06 \mathrm{~mL}$ on the $10^{\text {th }}$ day of bacteria cultivation in the medium with 60 and $90 \mathrm{mM}$ of sodium citrate and $\mathrm{NH}_{4}^{+}$, respectively (Fig. 4).

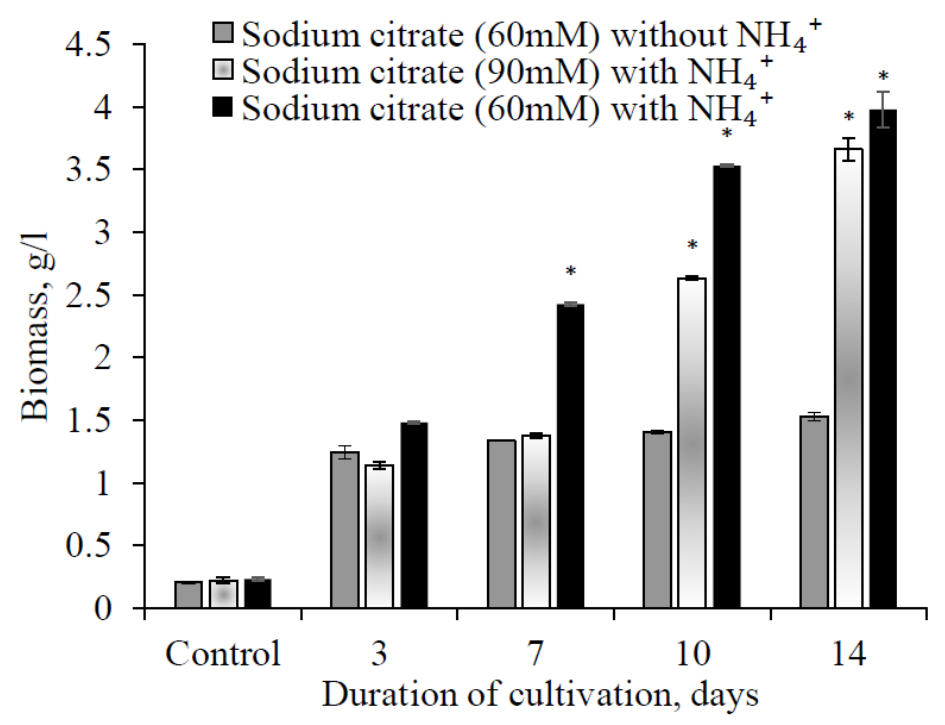

F i g. 1. Accumulation of biomass of Rhodopseudomonas yavorovii IMV B-7620 with the addition of different concentrations of sodium citrate and $\mathrm{NH}_{4}^{+}$and $60 \mathrm{mM}$ of sodium citrate without $\mathrm{NH}_{4}^{+}$ into the cultivation medium. Control was the cell biomass before cultivation, $x \pm S D, n=3$, * - probable changes compared with the control $(\mathbf{p}<0.05)$ 


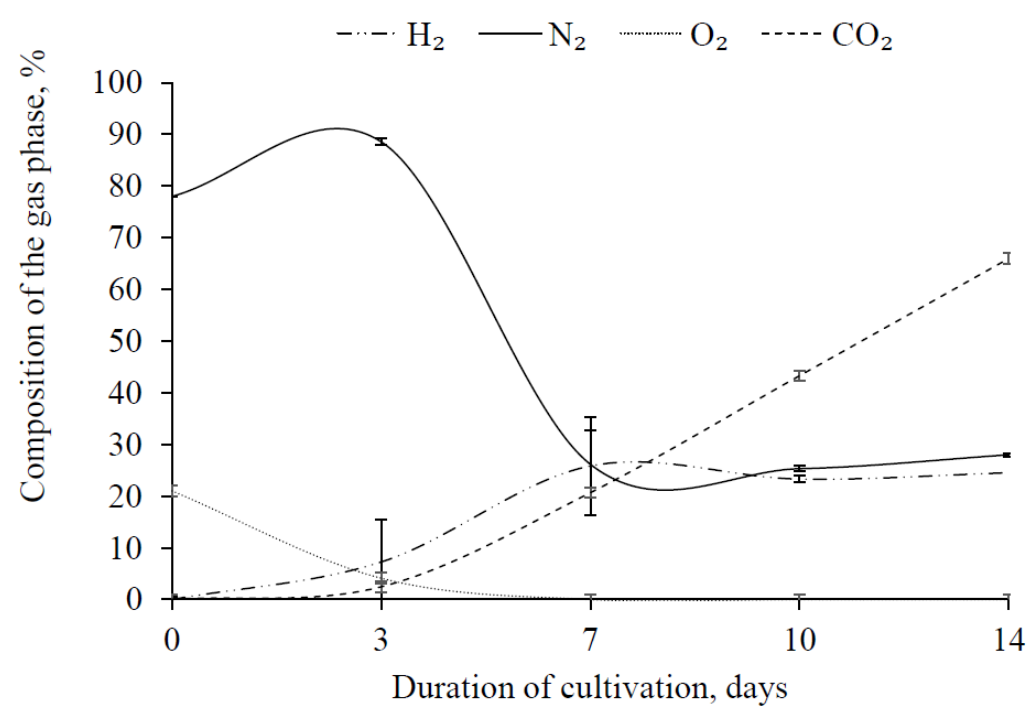

F i g. 2. The composition of the gas phase during the photofermentation of Rhodopseudomonas yavorovii IMV B-7620 in the medium with $60 \mathrm{mM}$ of sodium citrate and $\mathrm{NH}_{4}^{+}(x \pm \mathrm{SD}, \mathrm{n}=3)$

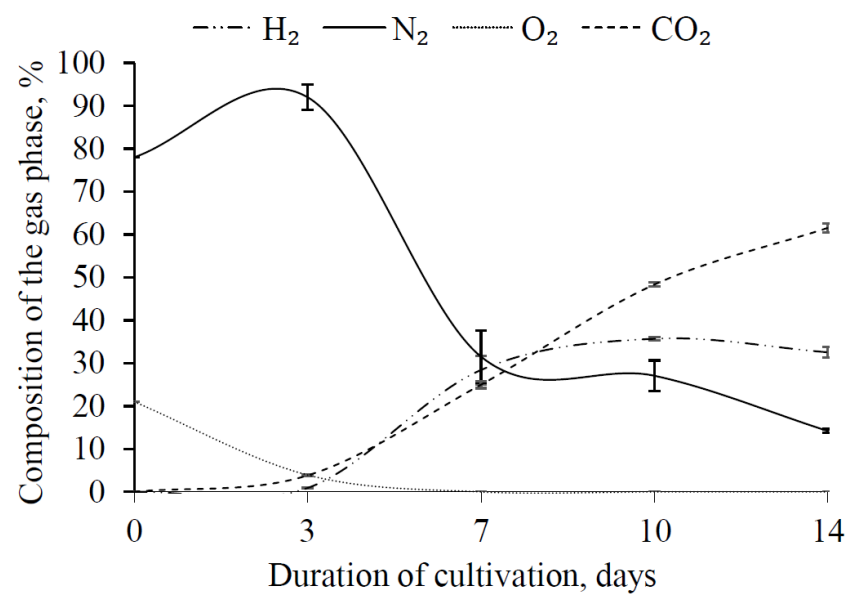

F i g. 3. The composition of the gas phase during the photofermentation of Rhodopseudomonas yavorovii IMV B-7620 in the medium with $90 \mathrm{mM}$ of sodium citrate and $\mathrm{NH}_{4}^{+}(\mathrm{x} \pm \mathrm{SD}, \mathrm{n}=3)$

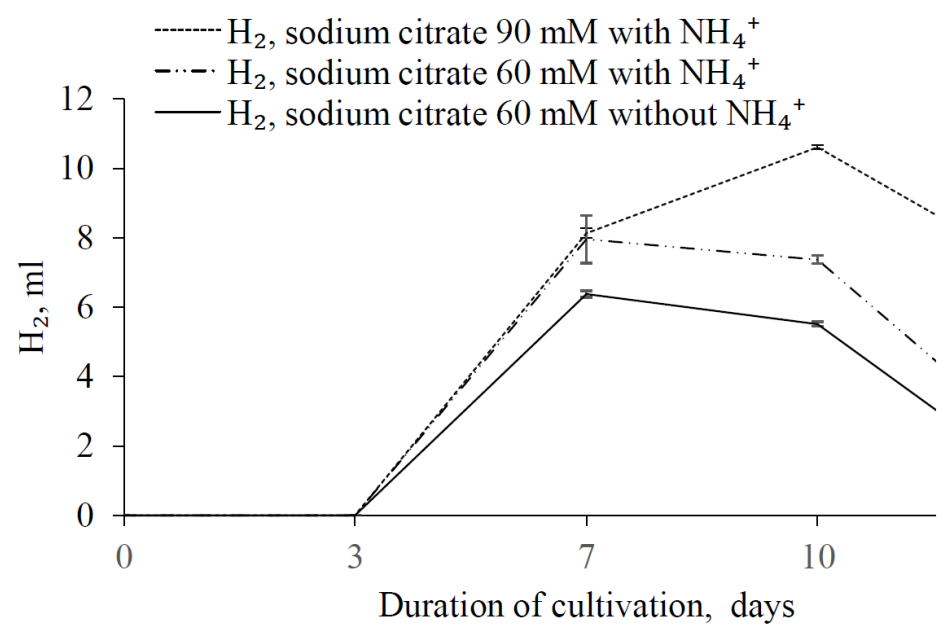

F i g. 4. Gas formation during photofermentation of 60 and $90 \mathrm{mM}$ of sodium citrate with the addition of $\mathrm{NH}_{4}{ }^{+}$and $60 \mathrm{mM}$ of sodium citrate without $\mathrm{NH}_{4}{ }^{+}$by $\mathrm{Rhodopseudomonas} \mathrm{yavorovii}$ IMV B-7620 ( $x \pm$ SD, $n=3)$ 
Determination of the mass balance of photofermentation of sodium citrate makes it possible to calculate the yield of $\mathrm{H}_{2}$. The total volume of gained hydrogen during the growth of $R$. yavorovii IMV B-7620 in a medium with $90 \mathrm{mM}$ sodium citrate and $\mathrm{NH}_{4}^{+}$was $25.54 \pm 0.49 \mathrm{~mL}$ of $\mathrm{H}_{2}$. It is 1.5 times higher than the volume of synthesized $\mathrm{H}_{2}$ during the growth of bacteria in a medium with $60 \mathrm{mM}$ of sodium citrate and $\mathrm{NH}_{4}^{+}$(see Fig. 4). Therefore, the maximum yield of hydrogen was observed during the growth of $R$. yavorovii IMV B-7620 in the cultivation medium with the addition of $90 \mathrm{mM}$ of sodium citrate and $\mathrm{NH}_{4}^{+}$.

Nitrogenase catalyzes the reduction of nitrogen to ammonia in purple photosynthetic bacteria accompanied by the production of hydrogen. However, this process is inefficient enough, since about $75 \%$ of the reducing agent is used to generate ammonia. However, hydrogen production by the studied microorganisms does not depend on nitrogen fixation. R. yavorovii IMV B-7620, as well as mutants of Rhodopseudomonas palustris $[26,27]$, are capable of producing hydrogen constitutively, even in the presence of $\mathrm{NH}_{4}^{+}$in the cultivation medium. It should be noted here that wild-type $R$. palustris cells do not produce hydrogen in the presence of ammonia [26, 27]. Bacteria produced 1.4 times less hydrogen during the growth of $R$. yavorovii IMV B-7620 in the medium with sodium citrate $(60 \mathrm{mM})$ without $\mathrm{NH}_{4}^{+}$ (see Fig. 4) in comparison with the cells cultivated in the medium with $\mathrm{NH}_{4}^{+}$(Fig. 4). The biomass of bacteria in the cultivation medium with $60 \mathrm{mM}$ of sodium citrate without $\mathrm{NH}_{4}^{+}$was $1.52 \pm 0.03 \mathrm{~g} / \mathrm{L}$ on the $14^{\text {th }}$ day of cultivation. It was 2.6 times less than with the addition of $\mathrm{NH}_{4}^{+}$into the cultivation medium (see Fig. 1). Therefore, increase in the substrate concentration from 60 to $90 \mathrm{mM}$ led to a slight decrease in the biomass accumulation and increased hydrogen production.

Discussion. Purple non-sulfur bacteria are widespread in nature. They inhabit water reservoirs rich in organics or that have a lot of silt, moist soil, saline water. These bacteria are isolated from hot springs and permafrost $[28,29]$. A wide variety of metabolic pathways was found to allow getting the necessary amount of energy for life processes in the group of purple non-sulfur bacteria. Due to the functioning of the second type of photosystem, these microorganisms are capable of anoxygenic photosynthesis and grow under phototrophic conditions. Organic or inorganic compounds, such as hydrogen, hydrogen sulfide, elemental sulfur can serve as their electron donors during the photosynthesis. Lots of samples of this group can grow without light under aerobic or microaerobic conditions, obtaining energy in the process of respiration using organic substances, in particular, organic acids or hydrogen. Phototrophic bacteria require the coordinated action of two enzymes: Mo$\mathrm{Fe}$-containing nitrogenase and Ni-Fe-containing hydrogenase to produce hydrogen during the photofermentation [5].

Purple non-sulfur bacteria are capable of phototrophic hydrogen production with the simultaneous consumption of organic substrates that may be wastes of various industries. This is why the process of hydrogen production involving these microorganisms is so potentially low-cost. The fact that the production of hydrogen occurs at atmospheric pressure and at temperatures of $+27 \ldots$ $+30^{\circ} \mathrm{C}$ is also the advantage of the process.

Attempts to optimize the cultivation conditions for various phototrophic bacteria in order to obtain high concentrations of hydrogen have been repeatedly made. They concerned the selection of organic acids and their optimal concentrations. Thus, it is shown for Rhodobacter sphaeroides strain OU 001 that malate is the best substrate for the generation of higher hydrogen concentrations ( $0.0042 \mathrm{~mL} \mathrm{H}_{2} \mathrm{~mL}^{-1}$ medium $\left.\mathrm{h}^{-1}\right)$, and the optimal $\mathrm{pH}$ for this process is 6.8 [6,30-32]. High hydrogen yield (3.88 $\mathrm{mol} \mathrm{H}_{2} \mathrm{~mol}^{-1}$ acetic acid) was observed in Rhodobacter sp. strain KKU-PS1 while growing in the medium with malate [33]. Studied by us bacteria $R$. yavorovii IMV B-7620 form $0.15 \pm 0.01$ and $1.5 \pm 0.03 \%$ of hydrogen, respectively, on the $7^{\text {th }}$ and $14^{\text {th }}$ days of cultivation in the medium with malate $(12 \mathrm{mM})$. Increasing the concentration of malate to $36 \mathrm{mM}$ led to an increase in hydrogen production of $R$. yavorovii IMV B-7620 to $7.64 \pm 0.04 \%$ on the $14^{\text {th }}$ day of cultivation. However, the maximum concentration of hydrogen in the gas phase $(21.26 \pm 0.08 \%)$ was determined on the $14^{\text {th }}$ day of cultivation in the medium with the addition of sodium citrate. We concluded that the concentration of hydrogen during the growth of $R$. yavorovii IMV B-7620 in the medium with sodium citrate at a concentration of $90 \mathrm{mM}$ with $\mathrm{NH}_{4}{ }^{+}$in the gas phase is rather high.

Many studies have reported that acetate is the optimal source of carbon for hydrogen production $[34,35,9,19,36]$. However, $R$. yavorovii IMV B-7620 does not produce hydrogen. It consumed this substrate further.

Hydrogen production does not depend on nitrogen fixation in $R$. yavorovii IMV B-7620. 
Studied bacteria as well as mutants of $R$. palustris $[26,27]$ produce hydrogen in the presence of $\mathrm{NH}_{4}^{+}$in the cultivation medium. $R$. yavorovii IMV B-7620 produced 1.4 times less hydrogen growing in the medium with sodium citrate $(60 \mathrm{mM})$ without $\mathrm{NH}_{4}^{+}$compared with bacteria grown in the medium with $\mathrm{NH}_{4}^{+}$. The biomass of bacteria in the cultivation medium with $60 \mathrm{mM}$ of sodium citrate without $\mathrm{NH}_{4}^{+}$on the $14^{\text {th }}$ day was 2.6 times lower than with $\mathrm{NH}_{4}^{+}$.

Conclusions. Thus, in this work, purple nonsulfur bacteria $R$. yavorovii IMV B-7620, isolated from Yavoriv Lake, were demonstrated to synthesize hydrogen during the photofermentation of organic compounds. It was found that the studied bacteria consume succinate, sodium citrate, malate, glucose, starch as sources for hydrogen production. The total volume of hydrogen during the growth of $R$. yavorovii IMV B-7620 in the medium with $90 \mathrm{mM}$ of sodium citrate and $\mathrm{NH}_{4}^{+}$is $25.54 \pm$ $\pm 0.49 \mathrm{~mL}$. Based on the obtained quantitative parameters of gas formation, these microorganisms were calculated to form $1.099 \mathrm{~L}_{\text {of }} \mathrm{H}_{2}$ during 7 days of photofermentation of $1 \mathrm{~kg}$ of absolutely dry mass of sodium citrate.

The aim of our further research is to optimize and increase the efficiency of $\mathrm{H}_{2}$ synthesis from organic waste using $R$. yavorovii IMV B-7620, as the bioconversion of organic waste to hydrogen not only stabilizes waste/wastewater, but is also a good pathway to obtain energy.

\section{ПРОДУКУВАННЯ ВОДНЮ ПУРПУРОВИМИ НЕСІРКОВИМИ БАКТЕРІЯМИ RHODOPSEUDOMONAS YAVOROVII IMB B-7620}

О.В. Тарабас ${ }^{1}$, С.О. Гнатуи', О.Б. Таширев ${ }^{2}$, В.М. Говоруха ${ }^{2}$, О.А. Гаврилюк ${ }^{2}$, О.М. Мороз, ${ }^{1}$ А.А. Галуика ${ }^{1}$

${ }^{1}$ Львівський наиіональний університет імені Івана Франка, вул. Грушевського, 4, Львів, 79005, Україна

${ }^{2}$ Інститут мікробіології і вірусології ім. Д.К. Заболотного НАН України, вул. Академіка Заболотного, 154, Київ, 03143, Украӥна

$$
\text { Р е } 3 \text { ю м е }
$$

Продукування водню мікроорганізмами досліджують за використання різних джерел живлення для їхнього культивування. Пурпурові несіркові бактерії здатні до фотовиділення водню з одночасним нагромадженням біомаси на органічних субстратах, які можуть бути відходами різних виробництв, що робить дослідження цієї групи мікроорганізмів перспективним. Мета. Визначення здатності продукувати водень пурпуровими несірковими бактеріями Rhodopseudomonas yavorovii IMB B-7620 за використання різних органічних субстратів та їхнього впливу на основні метаболічні показники росту культури. Методи. Бактеpiї вирощували у скляних банках об'ємом 100 мл у рідкому модифікованому середовищі АТСС № 1449 упродовж 14 діб за температури $+27 \ldots+30{ }^{\circ} \mathrm{C}$ та умов постійного освітлення (200 лк). Нагромадження біомаси та продукування водню у середовищі культивування визначали за внесення натрій ацетату (12 і $36 \mathrm{MM}$ ), малату (12 і $36 \mathrm{MM}$ ), сукцинату (36 мМ), глюкози (36 мM), крохмалю (36 мM), натрій цитрату (36, 60, 90 мM). Біомасу визначали турбідиметрично, склад газової фази - за використання газового хроматографа ЛХМ8-МД, окисно-відновний потенціал та рН - потенціометричним методом. Об'єм синтезованого газу вимірювали за шкалою шприца. Визначення вмісту органічних кислот у культуральній рідині проводили методом високоефективної рідинної хроматографії. Результати. Використання органічних сполук (малату, глюкози, крохмалю, натрій цитрату) у $R$. yavorovii IMB B-7620 супроводжується синтезом водню. Використовуючи натрій ацетат, бактерії нагромаджують у незначних кількостях сукцинат. За використання малату проміжними продуктами його метаболізму є невеликі кількості фумарату на 7 добу культивування та ізоцитрату - на 10 добу культивування. На 14 добу культивування у культуральній рідині є невелика кількість сукцинату. На 14 добу культивування у середовищі з малатом (36 мМ) $R$. yavorovii IMB В-7620 утворюють 7,64 $\pm 0,04 \%$ водню. Однак максимальну концентрацію водню у складі газової фази $(21,26 \pm 0,08 \%)$ визначили на 14 добу культивування у середовищі за використання натрій цитрату. Максимальна концентрація $\mathrm{H}_{2}$ у газовій фазі за росту у середовищі з натрій цитратом (60 мM) 3 внесенням у середовище $\mathrm{NH}_{4}^{+}$на 7 добу культивування становила $27,83 \pm 5,46$ та $35,69 \pm 0,40 \%$ - за збільшення концентрації натрій цитрату до 90 мМ на 10 добу культивування. Сумарний об'єм водню за росту $R$. yavorovii IMB В-7620 у середовищі 3 90 мМ натрій цитрату та $3 \mathrm{NH}_{4}^{+}$становив $25,54 \pm$ $\pm 0,49$ мл $\mathrm{H}_{2}$, що у 1,5 рази більше утвореного $\mathrm{H}_{2}$ 
за росту бактерій у середовищі з 60 мМ натрій цитрату з внесенням $\mathrm{NH}_{4}^{+}$. Висновки. Пурпурові несіркові бактерії $R$. yavorovii IMB В-7620, виділені 3 води озера Яворівське (Львівська обл., Україна), яке утворилося у результаті затоплення сіркового кар'єру, синтезують водень у процесі фотоферментації органічних сполук. Бактерії використо-

1. Kellogg WW, Schware R. Climate change and society: consequences of increasing atmospheric carbon dioxide. New York: Routledge; 2019.

2. Bolatkhan K, Kossalbayev BD, Zayadan BK, Tomo T, Veziroglu TN, Allakhverdiev SI. Hydrogen production from phototrophic microorganisms: reality and perspectives. International Journal of Hydrogen Energy. 2019; 44(12):5799-811. https://doi.org/10.1016/j.ijhydene.2019.01.092.

3. Debabrata D, Veziroglu TN. Hydrogen production by biological processes: a survey of literature. International Journal of Hydrogen Energy. 2001; 26:13-28. doi:10.1016/S03603199(00)00058-6.

4. Singh L, Wahid ZA. Methods for enhancing bio-hydrogen production from biological process: a review. Journal of Industrial and Engineering Chemistry. 2015; 21:70-80. https://doi org/10.1016/j.jiec.2014.05.035.

5. Das D, Veziroglu TN. Hydrogen production by biological processes: a survey of literature. International Journal of Hydrogen Energy. 2001; 26:13-28. doi:10.1016/S0360-3199(00)00058-6.

6. Basak N., Das D. The prospect of purple non-sulfur (PNS) photosynthetic bacteria for hydrogen production: The present state of art. World Journal of Microbial Biotechnology. 2007; 23:31-42. doi: 10.1007/s11274-006-9190-9.

7. Hankamer B, Lehr F, Rupprecht J, Mussgnug J, Posten C, Kruse O. Photosynthetic biomass and $\mathrm{H}_{2}$ production by green algae: from bioengineering to bioreactor scale-up. Physiology Plant. 2007; 131:10-21. doi: 10.1111/j.1399-3054.2007. 00924.x.

8. Tashyreva A, Tashyrev O, Prytula I. The Novel Comprehensive Approach for Agricultural and Landfill Biomass Microbial Fermentation and Biogas Production. Biotechnology and Plant Breeding Perspectives. 2014:347-356. вують натрій цитрат, малат, глюкозу, крохмаль i виділяють водень. Сумарний об'єм водню за росту R. yavorovii IMB B-7620 у середовищі з 90 мМ натрій цитрату та з $\mathrm{NH}_{4}^{+}$становить $25,54 \pm 0,49$ мл $\mathrm{H}_{2}$.

Ключові слова: водень, пурпурові несіркові бактерії, фотоферментація.

9. Lee CM, Chen PC, Wang CC, Tung YC. Photohydrogen production using purple nonsulfur bacteria with hydrogen fermentation reactor effluent. International Journal of Hydrogen Energy. 2002; 27:1309-1313. doi:10.1016/ S0360-3199(02)00102-7.

10. Gest H, Kamen MD. Photoproduction of molecular hydrogen by Rhodospirillum rubrum. Science. $1949 a$; 109:558-559. doi: 10.1126/science. 109.2840.558.

11. Gest H, Kamen MD. Studies on the metabolism of photosynthetic bacteria IV. Photochemical production of molecular hydrogen by growing cultures of photosynthetic bacteria. Journal of Bacteriology. 1949b; 58:239-245.

12. Fascetti E, Todini O. Rhodobacter sphaeroides $\mathrm{RV}$ cultivation and hydrogen production in one and two-stage chemostat. Applied Microbiology and Biotechnology. 1995; 44:330-305.

13. Fascetti E, D’addario E, Todini O, Robertiello A. Photosynthetic hydrogen evolution with volatile organic acids derived from the fermentation of source selected municipal solid wastes. International Journal of Hydrogen Energy. 1998; 23(9):753-760. https://doi.org/10.1016/S03603199(97)00123-7.

14. Federov AS, Tsygankov AA, Rao KK, Hall DO. Hydrogen photoproduction by Rhodobacter sphaeroides immobilized on polyurethane foam. Biotechnology Letters. 1998; 20:1007-1009. doi:10.1023/A:1005402904462.

15. He D, Bultel Y, Magnin JP, Roux C, Willison JC. Hydrogen photosynthesis by Rhodobacter capsulatus and its coupling to PEM fuel cell. Journal of Power Sources. 2005; 141:19-23.

16. Khanal SK, Chen WH, Li L, Sung S. Biological hydrogen production: effects of $\mathrm{pH}$ and intermediate products. International journal of hydrogen energy. 2004; 29(11):1123-1131. https://doi. 
org/10.1016/j.ijhydene.2003.11.002.

17. Lin $\mathrm{CY}$, Jo $\mathrm{CH}$. Hydrogen production from sucrose using an anaerobic sequencing batch reactor process. Journal of Chemical Technology \& Biotechnology. 2003; 78(6):678-684. doi: 10.1007/s12010-014-1170-1.

18. Singh SP, Srivastava SC, Pandey KD. Hydrogen production by Rhodopseudomonas at the expense of vegetatable starch, sugar cane juice and whey. International Journal of Hydrogen Energy. 1994; 19:437-440.

19. Tao YZ, He YL, Wu YQ, Liu FH, Li XF, Zong WM, et al.Characteristics of a new photosynthetic bacterial strain for hydrogen production and its application in wastewater treatment. International Journal of Hydrogen Energy. 2008; 33(3):963-973.

20. Tarabas O, Hnatush S, Ostash B, Mutenko G, Koshla O. [Identification of purple non-sulfur bacteria of Rhodopseudomonas sp. Ya-2016]. Visnyk of Lviv Univer. Biol. Series. 2017; 75:140-145. Ukrainian.

21. Drugov YuS, Berezkin VG. [Gas chromatographic analysis of polluted air]. Moscow:Chemistry, 1981. 256 p. Russian.

22. Kerem Z, Bravdo BA, Shoseyov O, Tugendhaft Y. Rapid liquid chromatography-ultraviolet determination of organic acids and phenolic compounds in red wine and must. Journal of Chromatography A. 2004; 1052(1-2):211-215. doi: 10.1016/j.chroma.2004.08.105.

23. Gabrielyan L, Trchounian A. Relationship between molecular hydrogen production, proton transport and the FOF1-ATPase activity in Rhodobacter sphaeroides strains from mineral springs. International Journal of Hydrogen Energy. 2009; 34, 2567-2572.

24. Guo WQ, Ren NQ, Wang XJ, Xiang WS, Meng ZH, Ding J, QuYY, Zhang LS. Biohydrogen production from ethanol-type fermentation of molasses in an expanded granular sludge bed (EGSB) reactor. International Journal of Hydrogen Energy. 2008; 33(19):49814988.

25. Tarabas O, Hnatush S, Govorukha V, Tashyrev O, Moroz O. Production of molecular hydrogen by purple non-sulfur bacteria Rhodopseudomonas yavorovii IMB B-7620. In: $7^{\text {th }}$ International Weigl Conference; $2017 a$ Sep 26-29; Ukraine, Lviv: abstract book, 2017. p. 188.

26. Oda Y, Star B, Huisman LA, Gottschal JC, Forney LJ. Biogeography of the purple non-sulfur bacterium Rhodopseudomonas palustris. Applied and Environmental Microbiology. 2003; 69(9):5186-5191.

27. Rey FE, Heiniger EK, Harwood CS. Redirection of Metabolism for biological hydrogen production. Applied and Environmental Microbiology. 2007; 73(5):1665-1671.

28. Hiraishi A, Nagao N, Yonekawa C, Umekage S, Kikuchi Y, Eki T, Hirose Y. Distribution of phototrophic purple nonsulfur bacteria in massive blooms in coastal and wastewater ditch environments. Microorganisms. 2020; 8(2):150. doi: 10.3390/microorganisms8020150.

29. Madigan MT. Anoxygenic phototrophic bacteria from extreme environments. Photosynthesis research. 2003; 76(1):157-171. doi: 10.1023/A: 1024998212684.

30. Eroglu I, Aslan K, Gunduz U, Yucel M, Turker L. Continuous hydrogen production by Rhodobacter sphaeroides O.U. 001. In: Zaborsky OR, editor. Biohydrogen held in London. Springer, Boston, MA. 1998. p. 143-151. ISBN 0-30646057-2.

31. Koku H, Gunduz U, Yucel M, Turker L. Kinetics of biological hydrogen production by the photosynthetic bacterium Rhodobacter sphaeroides OU 001. International Journal of Hydrogen Energy. 2003; 28:381-388.

32. Nath K, Kumar A, Das D. Hydrogen production by Rhodobacter sphaeroides strain OU 001 using spent media of Enterobacter cloacae strain DM11. Applied microbiology and biotechnology. 2005; 68(4):533-541. doi: 10.1007/s00253-0051887-4.

33. Assawamongkholsiri $\mathrm{T}$, Reungsang A. Photo-fermentation hydrogen production of Rhodobacter sp. KKU-PS1 isolated from an UASB reactor. Electronic Journal of Biotechnology. 2015; 18:221-230. https://doi.org/10.1016/j. ejbt.2015.03.011.

34. Blasco R, Cardenas J, Castillo F. Acetate metabolism in purple non-sulfur bacteria. FEMS micro- 
biology letters. 1989; 58(2-3):129-132. https:// doi.org/10.1111/j.1574-6968.1989.tb03032.x

35. Han HL, Jia QB, Liu BQ, Yang HJ, Shen JQ. Fermentative hydrogen production from acetate using Rhodobacter sphaeroides RV. International Journal of Hydrogen Energy. 2013; 38:1077310778.
36. Wang YZ, Liao Q, Zhu X, Tian X, Zhang C. Characteristics of hydrogen production and substrate consumption of Rhodopseudomonas palustris CQK 01 in an immobilized-cell photobioreactor. Bioresourses Technology. 2010; 101:4034-4041. doi:10.1016/j.biortech.2010.01.045.

Received 19.07.2021 